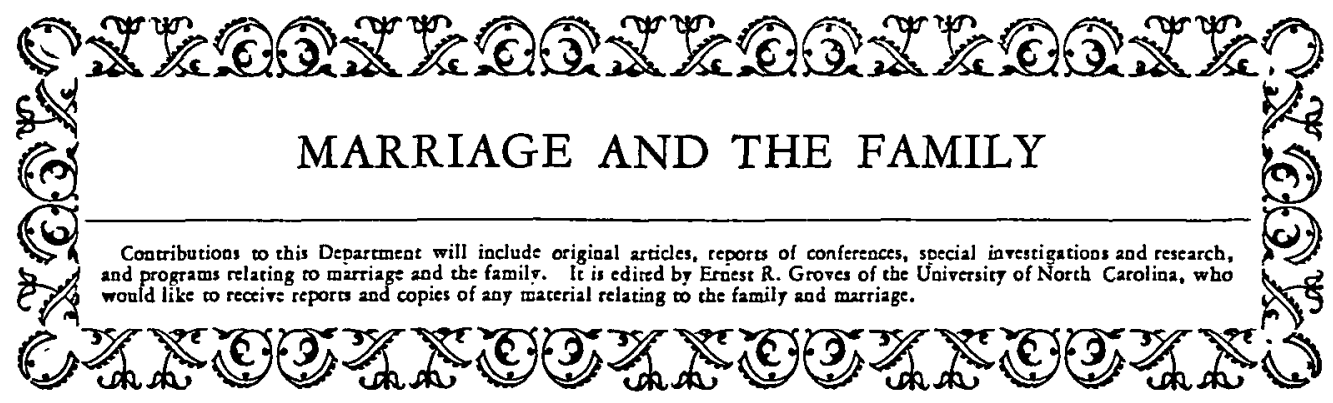

\title{
SOME DOMESTIC RELATIONS LAWS THAT COUNSELLORS IN MARITAL DIFFICULTIES NEED TO KNOW*
}

\author{
JOHN S. BRADWAY
}

\section{Duke University}

1 THE marriage counsellor, even when he is unaware of them, is constantly confronting problems of law. The lawyer must face many domestic situations where there is need for mature and experienced lay judgment and extra-legal skills, techniques, and resources. Sometimes one finds a marriage counsellor with adequate legal training, or a lawyer with broad human experience and other temperamental qualifications who combines in himself these at present unrelated abilities, and who alone can accomplish the entire task. Such a person is the exception. Too often neither the marriage counsellor nor the lawyer is equipped to handle successfully both aspects of such a family or individual difficulty.

One may assume that the watertight compartment theory of the social sciences, however valuable it may be for research purposes, has distinct limitations in the field of practical application. No one knows how many complex human difficulties fail to receive adequate attention, let alone solution, because of the lack of a medium for the ready interprofessional exchange of facilities. Among those people who have had contact with the situa-

* Adapted from remarks made before the Fourth Annual Conference on Conservation of Marriage and the Family, University of North Carolina, Chapel Hill, April 13, 1938. tion there is an impression of a substantial number of such failures. Since this paper is directed to marriage counsellors alone, one may consider the consequences of the neglect or refusal of the marriage counsellor to equip himself to make a fairly accurate diagnosis to determine the presence of possible legal problems. Three such consequences are obvious: He may violate some law and thus bring upon himself and the whole movement a publicity unwelcome if not actually harmful. He may endeavor to ignore or grapple with the legal problems thus, at least, jeopardizing the rights of his client; he may remain oblivious to the invaluable data in a statistical mass of such cases and thus neglect to contribute to the important task of moulding the law to cope with modern social and economic conditions.

This paper is devoted to outlining some possible remedies for this situation and contains specific proposals for the consideration of the marriage counsellors as a group. Recommendations for action must be deferred until the nature of the danger areas is charted.

\section{LAWS DIRECTLY AFFECTING MARRIAGE}

\section{ADVISERS}

Marriage counsellors, as individuals, are subject to the same rules of law which affect everyone. When they function as 
experts they inevitably encroach upon or advance toward the spheres of influence of certain specific rules of law giving the professional man broad exclusive privileges which are denied to the layman. Four examples will serve: Laws prohibiting the practice of law without a license; laws prohibiting the practice of medicine without a license; laws allowing an engaged person or a spouse to sue other persons (including marriage counsellors) for damages for alienating the affections of the other engaged person or spouse; laws providing that information given to representatives of certain professions, and only to those persons, may be held inviolate and confidential. Each of these examples deserves a few words of explanation.

\section{A. Unauthorized Practice of Law}

Within the last decade the organized bar has become increasingly concerned to prevent lay encroachments upon its own field which, in the public interest, it believes should be exclusive. As a result, statutes have been enacted in most of the states defining the practice of law in inclusive terms restricting this activity to licensed lawyers, and providing criminal and other penalties for a violation. The courts, interpreting such statutes in actual cases, have prosecuted trust companies, automobile clubs, collection agencies, insurance adjusters, and many others. They have also declared that the practice of the law is a matter ultimately for the judicial, rather than the legislative, department of government. This means that one who desires to learn his legal position must study the case law as well as the statutes of the state in which he conducts his work.

The immediate question is where does one draw the line in marriage counselling between acts which amount to practicing law and those which do not. Most people will feel that it is worth while to know where the line is drawn so as not to step over it. Even if one is determined to violate the law, he may find it interesting to know the consequences of his acts.

As an example of these laws, see that enacted in North Carolina in 1931, chapter 157, sec. I, which provides:

It shall be unlawful for any corporation or any person or association of persons, except members of the Bar of the State of North Carolina admitted and licensed to practice as attorneys-at-law, to appear as attorney or counselor-at-law, in any action or proceeding in any court in this State or before any judicial body or the North Carolina Industrial Commission; to maintain, conduct, or defend the same, except in his own behalf as a party thereto; or, by word, sign, letter, or advertisement, to hold out himself, or themselves, as competent or qualified to give legal advice or counsel, or to prepare legal documents, or as being engaged in advising or counselling in law or acting as attorney or counsellorat-law, or in furnishing the services of a lawyer or lawyers; and it shall be unlawful for any person or association of persons excepe members of the Bar, for a fee or any consideration, to give legal advice or counsel, perform for or furnish to another legal services, or for or without a fee or any consideration, to prepare directly or through another for another person, firm, or corporation, any will or testamentary disposition, or instrument of trust serving purposes similar to those of a will, exeept life insurance trusts, or, for a fee or any consideration, to organize corporations or prepare for another person, firm or corporation, any other legal document.

As an example of what the courts have to say on the subject, see a South Carolina case, In re Duncan, 65 S. E. 210:

It is too obvious for discussion that the practice of law is not limited to the conduct of cases in courts. According to the generally understood definition of the practice of law in this country, it embraces the preparation of pleadings and other papers incident to actions and special proceedings and the management of such actions and proceedings on behalf of clients before judges and courts, and in addition conveyancing, the preparation of legal instruments of all kinds, and in general all advice to clients and all action taken for them in matters connected with the law. An attorney at law is one who engages 
in any of these branches of the practice of law. The following is the concise definition given by the $\mathrm{Su}$ preme Court of the United States: "Personsacting professionally in legal formalities, negotiations or proceedings by the warrant or authority of their clients may be regarded as attorneys at law within the meaning of that designation as employed in this country."

Is it practice of the law for a marriage counsellor to: tell a client that he should get a divorce; tell a client the grounds for divorce; advance an opinion as to the possibilities of securing alimony and support; assist in the preparation of an agreement between the spouses as to their property. There are at present no cases giving a specific answer to these questions. The definitions of law practice supplied by legislatures and courts are so broad as to suggest that in a specific case a court might answer yes. Certainty is desirable. It may be secured in several ways. Someone may prepare a treatise on the subject, but it will be difficult to find authorities to support the various principles. The time honored way to secure the expression of a judicial opinion in a controverted subject is to have someone offer himself as a test case. The individual marriage counsellor may hesitate to take such a step. Other possible solutions will be considered hereafter.

\section{B. Unauthorized Practice of Medicine}

Similarly, the physicians, in the public interest, have sought to prohibit the practice of medicine by laymen. Statutes define practicing medicine and impose penalties for violations. As an example of such laws, see North Carolina Code, Section 6622:

No person shall practice medicine or surgery, or any of the branches thereof, nor in any case prescribe for the cure of diseases unless he shall have been first licensed and registered so to do in the manner provided in this article, and if any person shall practice medicine or surgery withour being duly licensed and registered, as provided in this article, he shall not be allowed to maintain any action to collect any fee for such services. The person so practicing without license shall be guilty of a misdemeanor, and upon conviction thereof shall be fined not less than fifty dollars (\$50) nor more than one hundred $(\$ 100)$, or imprisoned at the discretion of the court for each and every offense.

Any person shall be regarded as practicing medicine or surgery within the meaning of this act who shall diagnose or attempt to diagnose, treat or attempt to treat, operate or attempt to operate on, or prescribe for or administer to, or profess to treat any human ailment, physical or mental, or any physical injury to or deformity of another person: Provided, that the following cases shall not come within the definition above recited:

I. The administration of domestic or family remedies in cases of emergency.

2. The practice of dentistry by any legally licensed dentist engaged in the practice of dentistry and dental surgery.

3. The practice of pharmacy by any legally licensed pharmacist engaged in the practice of pharmacy.

4. The practice of medicine and surgery by any surgeon or physician of the United States army, navy, or public health service in the discharge of his official duties.

5. The treatment of the sick or suffering by mental or spiritual means without the use of any drugs or other material means.

6. The practice of optometry by any legally licensed optometrist engaged in the practice of optometry.

7. The practice of midwifery by any woman who pursues the vocation of midwife.

8. The practice of chiropody by any legally licensed chiropodist when engaged in the practice of chiropody, and without the use of any drug.

9. The practice of osteopathy by any legally licensed osteopath when engaged in the practice of osteopathy as defined by law, and especially six thousand seven hundred of the consolidated statutes.

ro. The practice of chiropractic by any legally licensed chiropractor when engaged in the manual adjustment of the twenty-four spinal vertebrac of the human body and without the use of drugs.

II. The practice of medicine or surgery by any reputable physician or surgeon in a neighboring state coming into this state for consultation with a residene registered physician. This proviso shall not apply to physicians resident in a neighboring state and regularly practicing in this state.

12. Physicians who have a diploma from a regu- 
lar medical college or were practicing medicine and surgery in this state prior to the seventh day of March, one thousand eight hundred and eightyfive, and who are properly registered by law.

Cases interpret the statutes. The marriage counsellor encroaches upon or approaches the prohibited area. A thorough understanding of where the line is drawn should prove of value to the individual and the group.

Is it practice of medicine for a marriage counsellor to: discuss birth control with a client; or to advise on personality diffculties; to suggest that an individual should not see a physician? There are at present few, if any, cases giving a specific answer to these questions. The definitions of the practice of medicine supplied by legislatures and courts are so broad as to suggest that in a specific case a court might answer yes. Certainty is desirable. It may be secured in several ways. Someone may prepare a treatise on the subject, but it will be difficult to find authorities to support the various principles. The time honored way to secure the expression of a judicial opinion on a controverted subject is to have someone offer himself as a human guinea pig in a test case. The individual marriage counsellor may hesitate to take such a step. Other possible solutions will be considered hereafter.

\section{Alienation of Affections and Similar Actions}

The law favors marriage and attempts to deter people from interfering with the formation of the marriage contract and from breaking up the family once it is organized. In a few states the legislatures recently have abolished suits for breach of promise and alienation of affections, but in general the right to sue still remains to the injured party. Parents and legal guardians are exempted from such liability because the law encourages them to counsel and advise their children. The marriage counsellor is not thus protected. No matter how laudable his motives, he is putting himself in a position where he may have to defend a suit for damages brought against him by the disappointed swain if he advises Mary to break her engagement to John or persuades Edward that he should cease living with his wife, Elsie. A suit for slander or libel will, of course, be possible if the character of the aggrieved party has been injured. Otherwise a suit for alienation of affections or some similar process may be brought.

The law is reasonably clear on this point and a treatise may be compiled which will inform marriage counsellors of their present position. It is quite likely that they may feel unduly cramped and will desire a change in the law. This, again, is a matter for further consideration.

\section{Confidential Communications}

When a client talks over with his lawyer his most personal affairs, the law protects the communication by throwing around it a mantle of confidentiality. The lawyer may not disclose, unless the client waives the privilege. Such a system is conducive to frank interchange of ideas. In many jurisdictions private conversations between husband and wife are cloaked legally in silence. In some states the clergyman-communicant and physician-patient relationships are similarly guarded. There appear to be no jurisdictions in which the marriage counsellor is thus protected. In consequence, if revelations are made in his presence by one spouse, the other may call the marriage counsellor as a witness. If he refuses to testify the judge may hold him in contempt of court and may punish him by fine or imprisonment for his continued silence. Obviously, some marriage coun- 
sellors will refuse to speak. There seems to be no reason for building up a group of martyrs or a great deal of questionable publicity if some other simpler solution is available. The law is reasonably clear on this point, and a treatise may be compiled which will inform marriage counsellors of their present position. It is quite likely that they may feel unduly cramped and will desire a change in the law. This again is a matter for further consideration.

Here are four rules of law which directly affect marriage counsellors. There are others. It would seem wise for marriage counsellors to learn about them and to work out methods and devices for coöperation with the legal and medical professions, rather than to run the risk of stumbling over a legal obstacle in the dark.

THE FAILURE TO UNDERSTAND THE WORKING OF THE LEGAL MIND

One of the most serious difficulties to public service by professional groups is the social distance which separates one profession from another and all professions from the lay members of the community. A professional man is a professional only as to his specialty. As to other matters he is a layman. The marriage counsellor may be an expert in his own field, but when he tries to use the resources of the law to aid in solving individual problems or when he ignores those resources he jeopardizes his client's rights.

Coöperation with lawyers is an excelient idea, but the process is one of mutuai education. For example, there must be agreement in lemine on such matters as the meaning of certain words which represent one idea to the layman and another to the lawyer. It is impracticable to make all marriage counsellors lawyers, or vice versa.

To attempt to familiarize the marriage counsellor with all the multitude of rules of law is a project as useless as it is enormous. More practical is the proposal to provide an instruction in legal first aid as part of the necessary preliminary training. A course in legal first aid may well cover two subjects:

\section{A. The Various Devices Employed in a Particular Jurisdiction to Accomplish Specified Objectives by Legal Means}

As an example, some contact with the procedures in breach of promise cases, annulment cases, non-support proceedings, divorce cases, and alimony petitions, will show the marriage counsellor the tools which the lawyer has available to use in domestic cases and the results which may be secured by their use. The question as to whether any of these tools is appropriate to the solution of a particular marital situation or whether the facts indicate the need for an appeal to the resources of some other professional field is a problem of legal diagnosis and may require the coöperative efforts of a marriage counsellor and a lawyer. Perhaps effective results can be obtained by an elementary treatise for outside reading followed in class by the discussion of a series of actual illustrative cases. One may assume an interesting series of discussions.

\section{B. The Various Steps a Lawyer may take in Handling a Specific Case}

Of late years the legal mind has been occupied by a consideration of the Judicial Process. Since a great muititude of cases never get to court it is necessary to include some acquaintance with the process in the mind of the practicing lawyer. There is little published material on this subject, so again the way is open for some enterprising person to supply a book on the subject to be followed by classroom discussions in which a lawyer attempts to 
discuss what goes on in his mind when he is thinking about a case. As examples one may list arbitrarily a series of steps.

I. The first question which a lawyer is likely to ask himself about a case is whether or not he desires to handle it. There are many factors determining his decision. The client may not have a set of facts of sufficient legal merit to make the lawyer feel there is a real legal question to be determined by the court or adjusted outside it. The lawyer may come to the conclusion that the client desires something which is unethical. It may be impracticable for the lawyer because of other clients who have previously retained his services for him to handle a new case in which he may be put in a position of representing conflicting interests or in the course of which he may come into the possession of information which should be kept confidential.

2. Another preliminary question confronting the lawyer is how to handle the case which presents some legal problems, but also requires for its complete solution the coördination of resources from some adjoining field. The client may be physically or mentally in need of the services of a physician or psychiatrist. Economic problems may be of such importance as to alter completely the handling of a particular case. How to accomplish these interprofessional adjustments so that all facets of his difficulty may be recognized, expertly allocated and solved requires careful planning and unusual vision. Here again coöperation between the lawyer and the marriage counsellor would seem to be important.

3. Another type of client is the one who desires from the lawyer no action, but merely seeks information as to his or her legal rights. Legal aid societies find that a large percentage of their clients are of this sort. The lawyer who would perform effectively in the presence of such queries needs to call upon the resources of the law and at the same time to tap business practice, and many other fields for aid. The similarity between this situation and that confronting the marriage counsellor is obvious.

4. If the client desires that action be taken the lawyer has three procedures at his disposal. He may conciliate, or litigate, or take steps to change the existing statute law. Which device he will employ depends upon his judgment as to how the case should be solved for the best interests of the client, and with due regard for the related interests of the court, the profession, and the community. In making up his mind on this point coöperation and exchange of ideas with a marriage counsellor may be very useful even though the marriage counsellor has no information or understanding of the technical procedures by which the ultimate goal is to be attained.

A course for marriage counsellors emphasizing the framework and tools of the legal field and the customary mental processes of the lawyer will go far toward bringing the two professional groups together and will reduce materially the number of cases now handled by either group on its own account in which better results for the client could be obtained by coöperation.

\section{REMEDIES}

In the foregoing material two situations have appeared calling for consideration: the present law limits the work of the marriage counsellor; no adequate machinery exists for an interprofessional coöperation.

Thete are three obvious steps which the marriage counsellor group may profitably 
take with respect to its relationship to the field of law:

I. Secure a general picture of the area of contact.

2. Learn something about the resources of the law and the method of functioning of the legal mind.

3. Utilize recurring realistic experiences as a basis for moulding rules of law which are proven to be inadequate, so as to accomplish ends recognized as socially desirable.

A general picture of the area of contact may be secured in at least three ways: informative books and articles may be written by lawyers and marriage counsellors, or perhaps by both, surveying the field; speakers may address conferences of marriage counsellors or conduct discussions on significant fields of law and clarify essential points; each marriage counsellor may well secure the coöperation and advice of a lawyer on specific cases. If this last is attempted, there should be adopted some such slogan as "See your lawyer twice a day."

A course in legal first aid will give the marriage counsellor an understanding of the resources of the law and the functioning of the legal mind.

If the law does not accomplish desirable social ends it is always possible, in an orderly manner, to change it. Legislative activity is no novelty and suitable facts laid before the proper committee of the general assembly of any state will receive consideration. The problems are the collection and interpretation of facts and the development and maintenance of channels of transportation to the law making body. The material available is unique and significant. The administrative task should be a simple one.

Relationship with the bar may require crystallization of the marriage counsellor group into a separate profession with admission requirements, standards for the conduct of the work, discipline, organization and all the other characteristics of the older professional groups. If this stage is reached it will be a simple matter to amend certain statutes to give the professional marriage counsellor a definite status. There may then be laws: punishing those who, without a license, give marriage advice; exempting marriage counsellors from suit because of their advice; providing for confidential communications. The limit of the jurisdiction of this new professional group may be determined with a high degree of precision. Inter-professional bridges may be built across socially interstitial gaps and the resources of the community enriched

Such a program, obviously, will consume a great deal of time for its perfection. During the interim the best practical step is for each marriage counsellor to arrange for the individual coöperation of a lawyer on the legal aspects of his cases. Such a partnership should benefit both participants, improve the service to the client, and build a foundation for greater service to the community. 